\title{
SELEKSI RUMPUT LAUT Kappaphycus striatum DALAM UPAYA PENINGKATAN LAJU PERTUMBUHAN BIBIT UNTUK BUDIDAYA
}

\author{
Andi Parenrengi\#, Mat Fahrur, Makmur, dan Sri Redjeki Hesti Mulyaningrum \\ Balai Penelitian dan Pengembangan Budidaya Air Payau
}

\begin{abstract}
ABSTRAK
Budidaya rumput laut di Indonesia semakin berkembang seiring dengan peningkatan permintaan bahan baku industri untuk pasar domestik dan eksport. Rumput laut Kappaphycus striatum, salah satu spesies rumput laut komersil, telah intensif dibudidayakan di perairan pantai. Saat ini, masalah utama yang dihadapi pembudidaya adalah rendahnya kualitas bibit yang berasal dari hasil budidaya. Seleksi varietas merupakan salah satu metode yang diharapkan dapat meningkatkan laju pertumbuhan rumput laut. Penelitian ini dilakukan dengan tujuan untuk mengetahui pengaruh seleksi varietas terhadap pertumbuhan rumput laut sehingga dapat dilakukan produksi bibit unggul untuk keperluan budidaya. Budidaya rumput laut $\mathrm{K}$. striatum telah dilakukan di Teluk Laikang Kabupaten Takalar Provinsi Sulawesi Selatan dengan menggunakan metode long line. Seleksi varietas dilakukan berdasarkan parameter laju pertumbuhan harian (LPH) dan metode seleksi mengacu pada protokol seleksi yang telah dikembangkan pada rumput laut $\mathrm{K}$. alvarezii. Hasil penelitian menunjukkan bahwa LPH bibit hasil seleksi lebih tinggi $(P<0,05)$ dibandingkan dengan kontrol, di mana LPH seleksi mencapai 3,47\%/hari, sedangkan LPH kontrol 1,81\% hari. Dari tiga siklus produksi bibit, rata-rata LPH hasil seleksi adalah 2,92\% /hari dan kontrol 1,58\% terjadi peningkatan sebesar $84,25 \%$ Kandungan karaginan dan kekuatan gel hasil seleksi relatif lebih tinggi dibandingkan kontrol, di mana LPH memiliki korelasi yang erat dengan kandungan karaginan $(r=0,6604)$ tetapi relatif lebih rendah dengan kekuatan gel $(r=0,1048)$. Kualitas air (salinitas, nitrat, fosfat, dan pH) selama penelitian berlangsung masih berada pada kisaran yang sesuai untuk pertumbuhan rumput laut.
\end{abstract}

\section{KATA KUNCl: seleksi varietas; pertumbuhan; bibit; rumput laut Kapppaphycus striatum}

ABSTRACT: Seaweed selection to enhance the growth rate of Kappaphycus striatum as seed for cultivation aquaculture development. By: Andi Parenrengi, Mat Fahrur, Makmur, and Sri Redjeki Hesti Mulyaningrum

\begin{abstract}
Seaweed cultivation in Indonesia has rapidly expanded following demands of seaweed as industrial raw materials for both domestic and export markets. Kappaphycus striatum, one of the commercial eucheumatoid seaweed species, has been intensively cultivated in the coastal waters. To date, one of the problems faced by seaweed farmers is low seed quality from cultivated seaweed. Mass selection of seaweed is hoped to be useful way in order to enhance the growth rate of seaweed to produce the high quality of seed for cultivation purpose. Seaweed K. striatum was cultivated at Laikang Bay, Takalar Regency South Sulawesi Province using long line method. Seaweed selection was carried out based on growth rateparameter and selection protocol was conducted based on trial studies developed to $\mathbf{K}$. alvarezii. The result of study showed that daily growth rate (DGR) of selected seaweed was significantly higher than control $(P<0.05)$, in which DGR of seed from selected seaweed reached to 3.47\% day while DGR of seed from control was $1.81 \%$ day. Among three cycles, the average of DGR from selection was $2.92 \%$ day, and control was $1.58 \%$ day, that it assumed that the DGR increased approximately $84.25 \%$ Carrageenan content and gel strength of selection was slightly higher than control, and DGR had a strong correlation with carrageenan content $(r=0.6604)$ and a low correlation with gel strength $(r=0.1048)$. Water qualities such salinity, nitrate, phosphate, and pH were suitable for growth of seaweed.
\end{abstract}

KEYWORDS: selection; growth rate; seed; seaweed Kappaphycus striatum

\footnotetext{
\# Korespondensi: Balai Penelitian dan Pengembangan Budidaya

Air Payau. Jl. Makmur Dg. Sitakka No. 129, Maros 90512,

Sulawesi Selatan, Indonesia. Tel. + (0411) 371544

E-mail: andi_parenrengi@ hotmail.com
} 


\section{PENDAHULUAN}

Rumput laut sudah dikenal sebagai bahan dasar dalam industri makanan, kosmetik, farmasi, maupun sebagai bahan pendukung dalam industri lain, seperti industri: kertas, tekstil, fotografi, semir sepatu, pasta gigi, pengalengan ikan/daging, dan pupuk. Manfaat tersebut menjadikan budidaya rumput laut mengalami perkembangan yang signifikan dengan ekspansi lahan di wilayah Indonesia akibat permintaaan bahan baku oleh pasar baik lokal maupun internasional.

Sejak tahun 2011, Indonesia telah menjadi produsen terbesar rumput laut penghasil karaginan dunia, di mana produksi mencapai 3.915.000 ton dibandingkan dengan Filipina sebesar 1.1801 .00 ton dan Korea sebesar 902.000 ton (FAO, 2012). Peningkatan produksi rumput laut di Indonesia semakin meningkat dan bahkan produksi pada tahun 2013 sudah mencapai 9.298.474 ton, sedangkan Filipina, Korea, dan Malaysia masing-masing hanya 1.558.378 ton, 1.131 .305 ton, dan 269.431 ton (FAO, 2015). Ekspor rumput laut Indonesia pada tahun 2012 juga menunjukkan nilai yang cukup besar yakni mencapai USD 134.348.000 (Ma'ruf, 2013). Penyumbang produksi dan ekspor rumput laut didominasi oleh kelompok Rhodobhyceae atau alga merah dari genus Kappaphycus/Eucheuma dan Gracilaria (Parenrengi, 2013a).

Rumput laut K. alvarezii merupakan rumput laut yang paling populer dengan nama Eucheuma cottonii (Ask \& Azanza, 2002) di samping beberapa spesies lainnya seperti E. denticulatum dan K. striatum. Rumput laut K. striatum merupakan rumput laut yang lebih dikenal dengan nama "sakul" dengan bentuk morfologi yang membulat seperti bola dengan warna yang cenderung hijau gelap atau terang (Gambar 1). Ciri morfologi tersebut yang membedakan dengan spesies rumput laut penghasil karaginan lainnya.

Produksi rumput laut yang cendeung meningkat dari tahun ke tahun disebabkan karena budidaya rumput laut dapat dilakukan dengan menggunakan teknologi yang relatif sederhana, tenaga kerja yang dapat dilakukan dari berbagai kalangan, dan periode produksi yang singkat, yaitu hanya 45 hari. Selain itu, proses pemanenan yang mudah dengan biaya yang murah, serta produksi bahan baku dapat disimpan dalam waktu yang lama.

Berdasarkan berbagai pertimbangan, sejak tahun 2010 Indonesia telah mencanangkan 2,6 juta ha dipersiapkan untuk lahan budidaya rumput laut (Parenrengi, 2013b). Beberapa penelitian telah dilakukan dalam mendukung program industrialisasi rumput laut, seperti: kesesuaian lahan budidaya (Pongmasak et al., 2010; Radiarta et al., 2012, Suhaimi et al., 2012), karakterisasi genetik (Parenrengi et al., 2006; Parenrengi et al., 2007; Sulaeman et al., 2007), produksi benih baik konvensional maupun kultur jaringan (Amini \& Parenrengi, 1995; Suryati et al., 2008; Mulyaningrum et al., 2013), metode budidaya (Pongmasak \& Tjaronge, 2010), hama dan penyakit (Pongmasak, 2010), dan strategi pengembangan budidaya rumput laut (Paena et al., 2010; Priono \& Andriyanto, 2012; Hadie \& Hadie, 2012). Meskipun demikian, penelitian mengenai peningkatan laju pertumbuhan melalui seleksi varietas rumput laut masih terbatas pada K. alvarezii (Pongmasak et al., 2013; 2014; 2015; Pongmasak \& Priono, 2015; Parenrengi et al., 2014) sedangkan seleksi rumput laut K. striatum belum pernah dilakukan.

Budidaya rumput laut telah meluas secara pesat, meskipun demikian dalam pengembangannya masih didapatkan berbagai masalah yang dihadapi oleh pembudidaya terkait dengan kualitas benih. Saat ini, benih yang dihasilkan dari hasil budidaya memperlihatkan kualitas yang semakin menurun dengan indikasi pertumbuhan yang relatif lambat atau kerdil, di samping juga masalah penyakit khususnya penyakit ice-ice. Keterbatasan benih dari alam dan penggunaan benih hasil budidaya yang berulang diduga merupakan salah satu penyebab penurunan kualitas benih sehingga rentan terhadap mutu lingkungan jelek dan penyakit (Gunawan, 1987). Jika masalah tersebut tidak segera dipecahkan maka diperkirakan akan berdampak pada produksi rumput laut di masa mendatang. Peningkatan potensi genetik dan laju pertumbuhan merupakan alternatif meto de yang dapat dilakukan untuk mendapatkan benih unggul untuk keperluan budidaya. Untuk mengatasi masalah tersebut, seleksi strain/varietas perlu dilakukan untuk menghasilkan bibit rumput laut yang memiliki pertumbuhan yang lebih cepat dibandingkan dengan bibit yang dihasilkan dari budidaya. Oleh karena itu, penelitian seleksi rumput laut K. striatum dilakukan dengan tujuan untuk menghasilkan bibit rumput laut yang memiliki keunggulan laju pertumbuhan yang lebih cepat.

\section{BAHAN DAN METODE}

\section{Koleksi Sampel}

Sampel rumput laut K. striatum dikoleksi dari pembudidaya di sekitar perairan Kabupaten Takalar, Sulawesi Selatan. Rumput laut K. striatum dipilih dari hasil budidaya dengan umur pemeliharaan 30 hari. Rumput laut dikumpulkan kemudian dilakukan penentuan spesies berdasarkan indentifikasi secara morfologi yang difokuskan pada bentuk dan pola percabangan, serta warna khas yang dimiliki. Rumput laut dipindahkan ke lokasi penelitian dengan 
mengikuti prosedur standar transportasi benih rumput laut. Rumput laut selanjutnya diaklimatisasi dengan cara melakukan pemeliharaan rumput laut di lokasi penelitian selama 30 hari untuk menghasilkan stok indukan (Gambar 1) yang akan digunakan sebagai bahan seleksi varietas.

\section{Budidaya dan Prosedur Seleksi}

Kegiatan penelitian dilaksanakan di perairan Pesisir Teluk Laikang Kabupaten Takalar, Sulawesi Selatan (Gambar 2) dan di Laboratorium Balai Penelitian dan Pengembangan Budidaya Air Payau (BPPBAP) di Maros, Sulawesi Selatan. Indukan bibit rumput laut K. striatum yang berasal dari beberapa daerah sentra budidaya rumput laut dengan bobot awal $50 \mathrm{~g}$ diikat dengan jarak $15 \mathrm{~cm}$ antar simpul pada tali bentangan. Rumput laut tersebut dipelihara pada lokasi yang sesuai dan dapat dilakukan sepanjang tahun. Pengukuran pertumbuhan bobot setiap ikatan dilakukan pada awal dan akhir pemeliharaan, yaitu pada awal pemeliharaan dan setelah umur 30 hari. Pada akhir pemeliharaan dilakukan seleksi untuk memilih bibit yang memiliki performansi pertumbuhan terbaik untuk ditanam kembali pada siklus budidaya berikutnya. Sebelum dilakukan budidaya, beberapa tahapan dilakukan, yaitu antara lain: penyiapan konstruksi budidaya, penyediaan stok induk, pengikatan bibit, perawatan/pemeliharaan, dan teknis seleksi bibit.

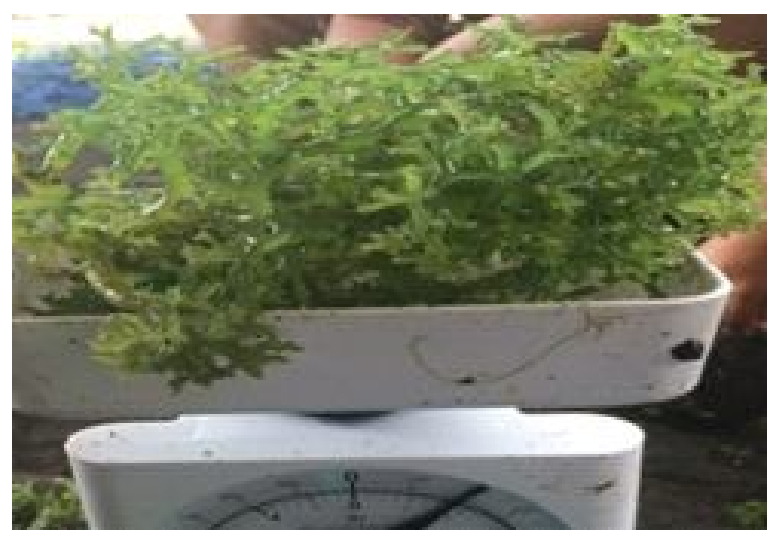

Gambar 1. Stok indukan rumput laut dari spesies Kappaphycus striatum yang dikoleksi dari hasil budidaya di perairan Takalar

Figure 1. Parent stock of seaweed of Kappaphycus striatum collected from a farm at Takalar waters

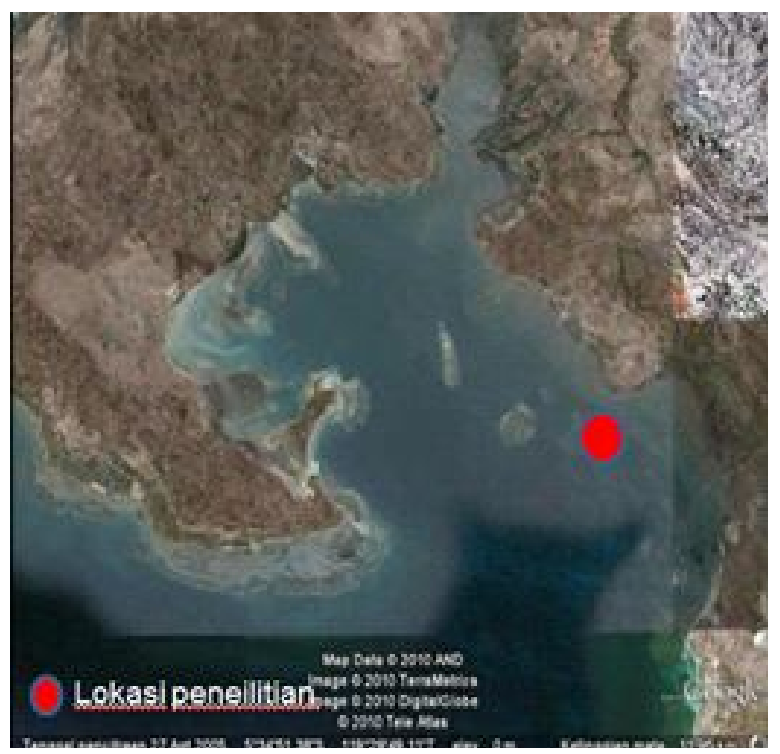

Gambar 2. Lokasi penelitian seleksi rumput laut Kappaphycus striatum di Teluk Laikang Kabupaten Takalar, Sulawesi Selatan

Figure 2. Study site for strain selection of seawed Kappaphycus striatum at Laikang Bay Takalar District, South Sulawesi 


\section{Persiapan Konstruksi Budidaya}

Setelah penentuan lokasi, maka dilakukan persiapan konstruksi pada lahan budidaya berukuran luas $50 \mathrm{~m} \times 40 \mathrm{~m}$. Panjang tali bentangan $40 \mathrm{~m}$ dengan jarak antar tali bentangan $1 \mathrm{~m}$, sehingga diperoleh 50 tali bentangan dalam satu unit konstruksi budidaya. Pada setiap tali bentangan dibuat jarak $15 \mathrm{~cm}$ untuk mengikatkan tali rumpun, sehingga setiap tali bentangan memuat 250 titik rumpun bibit. Jarak antar tali rumpun dibuat sama sehingga ruang untuk pertumbuhan bibit, termasuk dalam memperoleh suplai nutrien dalam perairan adalah sama.

\section{Penyediaan Stok Induk}

Penyediaan bibit dari populasi stok indukan K. striatum hasil aklimatisasi di lokasi penelitian memiliki beberapa kriteria. Kriteria tersebut antara lain: (a) memiliki thallus bercabang banyak, rimbun, dan ujung-ujung thallus agak runcing, (b) thallus rumput laut secara morfologi kelihatan bersih, segar, dan berwarna cerah, (c) umur indukan 30 hari, (d) thallus tidak berlendir, rusak, patah, berbau busuk pada saat akan dilakukan penanaman, dan (e) thallus bebas dari penyakit (bercak-bercak putih dan terkelupas) dan biofouling.

\section{Pengikatan Bibit}

Pengikatan bibit dilakukan di tempat yang teduh di pinggir pantai, sehingga memudahkan untuk menyiram/membasahi bibit selama proses pengikatan. Cara pengikatan bibit, sebagai berikut: (a) bibit ditimbang dengan bobot awal $50 \mathrm{~g}$ per rumpun menggunakan timbangan dengan skala ketelitian 0,1 g dengan bobot awal yang sama antar rumpun, (b) setiap rumpun bibit diikat dengan baik pada percabangan thallus sehingga tidak mudah lepas saat dipelihara, (c) melakukan pencatatan bobot, kondisi, dan urutan nomor setiap rumpun bibit dalam setiap bentangan sebagai data awal, (d) setelah pengikatan bibit pada setiap bentangan, maka segera ditanam agar bibit tidak mengalami kekeringan, layu, dan stres.

\section{Perawatan/Pemeliharaan}

Metode pemeliharaan bibit disesuaikan dengan kondisi lingkungan perairan dan metode budidaya yang digunakan yaitu metode apung sistem tali panjang (long line). Penanaman bibit dilakukan pada kedalaman rataan $30 \mathrm{~cm}$ dari permukaan perairan agar tidak terekspos langsung oleh sinar matahari. Perawatan bibit rumput laut pada saat arus air lemah dilakukan dengan menggoyang bentangan bibit sehingga partikel/lumpur yang menempel dapat lepas dari thallus. Perawatan juga dilakukan terhadap tali bentangan yang saling melilit akibat pengaruh ombak. Dilakukan pengamatan terhadap hewan pemangsa supaya tidak mengganggu dan memakan rumpun yang sedang dalam proses seleksi. Pemantauan biofouling juga dilakukan untuk mencegah hama dan biota penganggu bibit.

\section{Teknis Seleksi Bibit}

Rumput laut yang telah dipelihara selama 30 hari dijadikan sebagai populasi stok indukan baru (G-0) yang digunakan sebagai bahan untuk seleksi rumput laut. Prosedur seleksi yang digunakan mengacu pada protokol yang telah dikembangkan oleh Pongmasak et al. (2011) dengan menggunakan indikator seleksi berupa laju pertumbuhan harian (LPH), di mana seleksi dilakukan pada $10 \%$ LPH tertinggi pada setiap siklus pemeliharaan dan afkir atau sisanya (cut off) dijadikan sebagai bibit untuk digunakan sebagai kontrol internal dalam penelitian ini. Semua rumpun dalam setiap ikatan ditimbang bobotnya secara berurutan, kemudian dihitung LPH berdasarkan rumus yang dikembangkan oleh Raikar et al. (2001). Setelah semua rumpun rumput laut dalam satu bentangan ditimbang, maka seleksi dilakukan kepada 10\%LPH tertinggi yang selanjutnya dijadikan sebagai bahan bibit awal untuk siklus selanjutnya (G-1). Demikian juga rumpun sisa hasil seleksi (cut off) tetap dijadikan bibit untuk dipelihara pada siklus berikutnya sebagai kontrol internal. Bibit hasil seleksi dan kontrol internal dipelihara pada lokasi yang sama dengan menggunakan pengkodean yang jelas pada setiap bantangan dan setiap rumpun. Pemeliharaan siklus berikutnya dilakukan selama 30 hari untuk mendapatkan G-2. Seleksi dilakukan untuk mendapatkan varietas dari G-1 sampai G-n, dan seleksi dilakukan dengan proses yang sama dengan siklus sebelumnya untuk tiga siklus sampai LPH telah memperlihatkan nilai yang stabil. Pada umumnya, semakin lama seleksi dilakukan maka jumlah rumpun yang diafkir semakin sedikit tetapi sebaliknya jumlah rumpun yang diseleksi semakin besar atau semakin stabil, yang diilustrasikan dengan tanda panah pada Gambar 3. Pada setiap siklus dilakukan pengamatan kandungan karaginan dan kekuatan gel.

\section{Pengamatan Kandungan Karaginan, Kekuatan Gel, dan Kualitas Air}

Pengamatan kandungan karaginan dan kekuatan gel dilakukan setiap 30 hari pemeliharaan atau pada saat panen bibit selama tiga siklus pemeliharaan. Pengamatan kandungan karaginan rumput laut dilakukan dengan mengacu pada metode konvensional (Mulyaningrum et al., 2009) dengan komposit sampel. Sampel rumput laut dicuci dengan air tawar untuk menghilangkan kandungan garam dan kontaminasi dengan kotoran lainnya. Sampel selanjutnya direndam selama dua hari kemudian dipanaskan pada autoklaf 


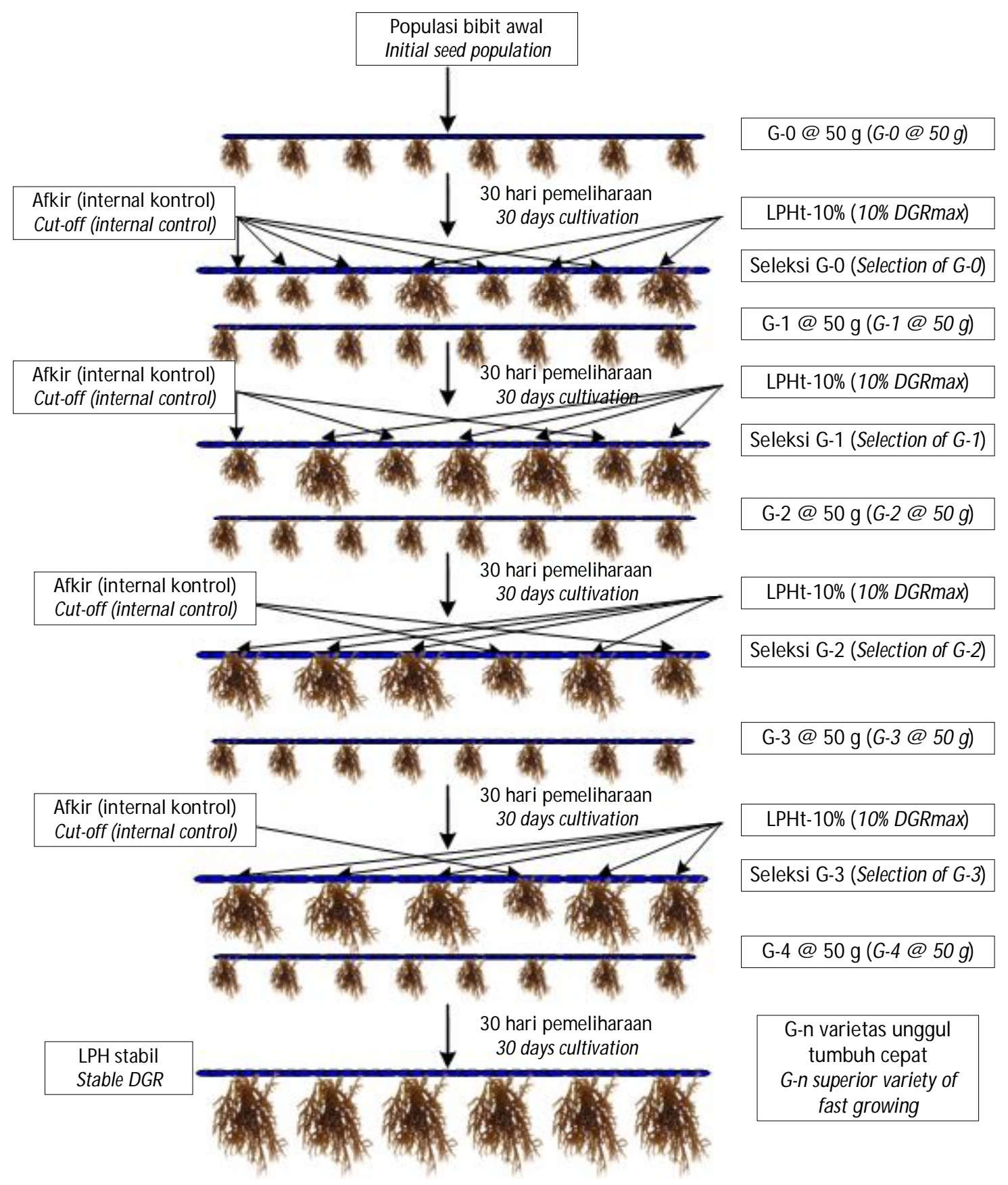

Gambar 3. Prosedur seleksi rumput laut berdasarkan parameter laju pertumbuhan harian (adopsi illustrasi dari Pongmasak et al., 2011)

Figure 3. The procedure of seaweed selection protocol based on the growth rate parameter (adapted illustration from Pongmasak et al., 2011)

dengan suhu $120^{\circ} \mathrm{C}$ selama 15 menit dengan menggunakan air sebagai pelarut dengan rasio rumput laut (g) dengan air (mL). Pemasakan sampel yang kedua dilakukan pada suhu $100^{\circ} \mathrm{C}$ selama 30 menit sampai rumput laut tersebut lunak sempurna. Sampel kemudian diblender dan diekstraksi menggunakan air panas dengan rasio 1:30 dan kemudian sampel disaring. Sampel dikentalkan dengan propanol pada rasio 1:2,5 untuk menjadikan larutan menjadi gel. Gel yang terbentuk selanjutnya dikeringkan pada suhu ruangan yang selajutnya dilakukan penimbangan untuk mengetahui bobot gel yang dihasilkan. Sedangkan kekuatan gel secara komposit juga diukur dengan menggunakan alat texture analyzer apparatus berdasarkan referensi dari Marine Colloid (1977). Pengamatan kualitas air seperti salinitas, nitrit, fosfat, 
dan $\mathrm{pH}$ dilakukan setiap 30 hari. Pengamatan salinitas dan $\mathrm{pH}$ dilakukan langsung di lapangan secara in-situ, sedangkan pengamatan nitrat dan fosfat dilakukan di laboratorium akreditasi BPPBAP, Maros.

\section{Analisis Data}

Hasil perhitungan LPH dianalisis dengan menggunakan program t-student dengan membandingkan antara LPH rumput laut yang diseleksi dengan rumput laut yang tidak diseleksi atau kontrol internal. Hasil pengamatan kandungan karaginan dan kekuatan gel antara rumput laut seleksi dengan kontrol dibahas secara deskriptif sedangkan hasil analisis kualitas air disajikan secara deskriptif dalam bentuk tabel. Untuk mengetahui pengaruh perlakuan maka data dianalisis t-student yang ditentukan pada level signifikasi 0,05 .

\section{HASIL DAN BAHASAN}

\section{Laju Pertumbuhan Harian}

Laju pertumbuhan harian (LPH) rumput laut $K$. striatum mengalami peningkatan pada perlakuan seleksi dibandingkan dengan bibit yang tidak diseleksi (kontrol) pada semua siklus budidaya yang dilakukan. Kecenderungan peningkatan LPH terjadi dari siklus pertama sampai dengan siklus ketiga. LPH rumput laut K. striatum meningkat dari 2,26\% hari dan kemudian 3,47\% hari masing-masing pada siklus pertama, kedua, dan ketiga (Gambar 4). Dari tiga siklus produksi bibit, rata-rata LPH hasil seleksi adalah 2,92\% /hari dan kontrol 1,58\% /hari; terjadi peningkatan sebesar $84,25 \%$ Pola peningkatan LPH yang sama juga terjadi pada K. striatum kontrol di mana siklus pertama, kedua, dan ketiga dengan nilai 1,13\% $1,82 \%$ dan $1,81 \%$ per hari, yang secara umum nilai tersebut masih lebih rendah dibandingkan dengan hasil seleksi. Analisis t-student menunjukkan bahwa rumput laut hasil seleksi memiliki LPH yang lebih tinggi $(P<0,05)$ dibandingkan dengan LPH kontrol.

Hasil penelitian ini menunjukkan bahwa aplikasi seleksi varietas dalam memproduksi bibit rumput laut K. striatum dapat meningkatkan pertumbuhan untuk siklus berikutnya. Hal yang sama telah dibuktikan pada spesies dan strain rumput laut lainnya, misalnya spesies K. alvarezii strain Gorontalo (dikenal dengan strain kulit buaya) dan Takalar, serta spesies Eucheuma denticulatum yang indukannya berasal dari alam perairan Nusa Tenggara Timur (Parenrengi et al., 2014). Hasil penelitian tersebut menunjukkan bahwa rumput laut K. alvarezii strain Takalar memperlihatkan pertumbuhan yang lebih tinggi pada bibit hasil seleksi yakni 6,49\%6,83\%/hari dibandingkan dengan kontrol sebesar 4,87-4,93\%/hari; serta strain kulit buaya masing-masing adalah 2,95\%5,07\% /hari dan 0,85\% 2,71\% /hari. Kecenderungan demikian juga didapatkan pada implementasi seleksi strain pada E. denticulatum pada bibit yang stok indukannya berasal dari alam, di mana hasil seleksi memperlihatkan pertumbuhan yang lebih tinggi (1,77\%2,74\% /hari) dibandingkan dengan kontrol (1,15\%1,25\% /hari). Pongmasak et al. (2014) melaporkan bahwa penerapan protokol seleksi pada rumput laut K. alvarezii pada tahun 2010 dan 2012 dapat meningkatkan pertumbuhan sebesar 15\%42\%

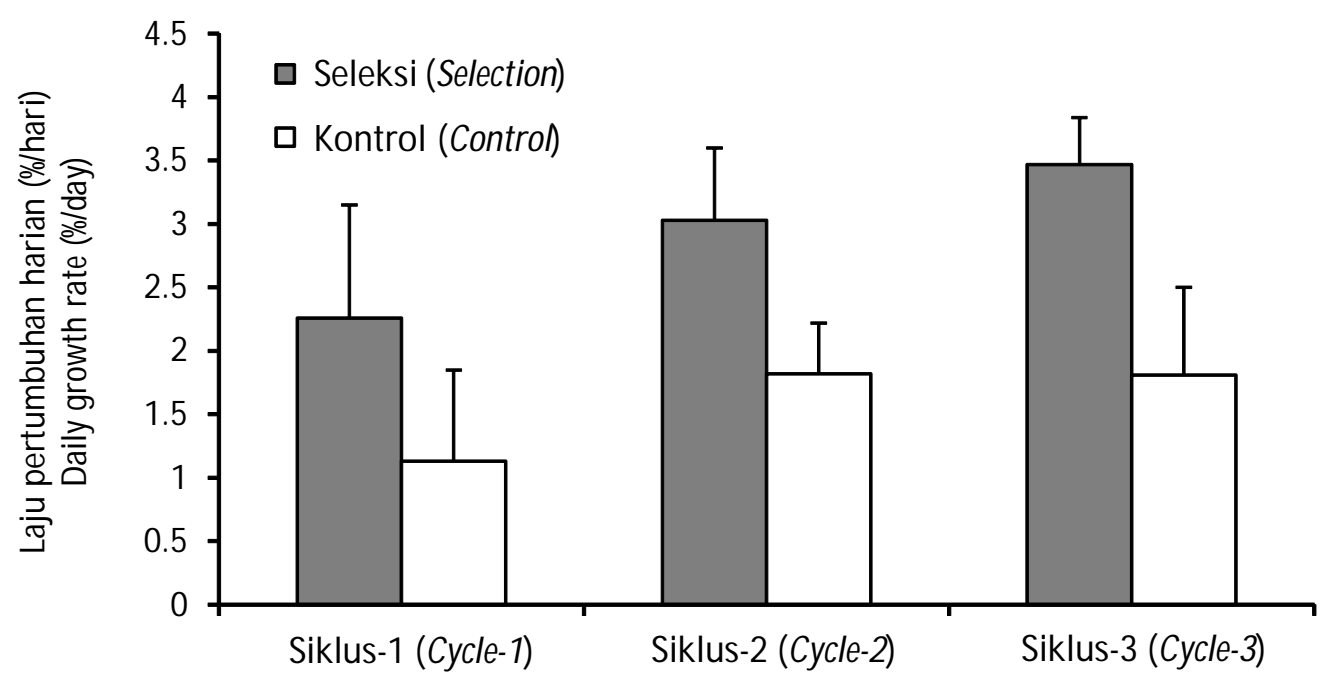

Gambar 4. Laju pertumbuhan harian rumput laut Kappaphycus striatum pada bibit hasil seleksi dan kontrol

Figure 4. Daily growth rate of seaweed Kappaphycus striatum from selected seed and control 
Tingginya pertumbuhan rumput laut seleksi diduga juga akibat distribusi hormon pertumbuhan tanaman berbeda antara rumpun atau cabang rumput laut. Fadillah (2014) melaporkan bahwa rumput laut $\mathrm{K}$. alvarezii hasil seleksi, selain memiliki pertumbuhan yang lebih tinggi, juga memiliki konsentrasi hormon pertumbuhan tanaman khususnya kinetin lebih besar $15,52 \%$ dibandingkan dengan rumput laut kontrol internal. Pongmasak et al. (2014) melaporkan bahwa dengan seleksi verietas $K$. alvarezii dapat meningkatkan pertumbuhan sebesar $32 \% 40 \%$ Selanjutnya penerapan seleksi varietas rumput laut $\mathrm{K}$. alvarezii dengan metode seleksi $10 \% \mathrm{LPH}$ tertinggi dapat menghasilkan bibit unggul dengan indikator peningkatan LPH sebesar 22,3\% (Pongmasak et al., 2015b).

Berbeda halnya dengan seleksi pada ikan atau udang, di mana pada umumnya seleksi dilakukan melalui proses perkawianan induk untuk mendapatkan generasi selanjutnya. Pada seleksi varietas/strain rumput laut, produksi bibit pada setiap generasi hanya dilakukan melalui proses perbanyakan vegetatif untuk mendapatkan generasi selanjutnya atau dikenal dengan siklus produksi bibit (Pongmasak et al., 2011). Oleh karena itu, penentuan heritabilitas tidak dapat dilakukan, sehingga diferensial seleksi hanya dihitung dari selisih rerata LPH yang terseleksi dengan populasi kontrol pada siklus tersebut. Sedangkan respons seleksi hanya dapat diestimasi berdasarkan peningkatan LPH seleksi dibandingkan dengan LPH kontrol internal. Diferensial seleksi yang didapatkan pada penelitian ini adalah 1,44\%2,27\% /hari $(47,52 \%$ $75,17 \%$, sedangkan estimasi respons seleksi berkisar antara 1,13\%1,66\% /hari $(66,48 \% 100 \%$ (Tabel 1). Nilai diferensial seleksi yang didapatkan pada penelitian ini lebih rendah dibandingkan dengan diferensial seleksi pada ikan lele (Clarias gariepinus) tumbuh cepat hasil seleksi individu $(130,57 \% 180,40 \%)$ untuk tiga generasi, tetapi respons seleksinya lebih kecil yakni $11,8 \% 20,59 \%$ (Imron et al., 2014). Rohmana et al. (2014) melaporkan bahwa respons seleksi yang didapatkan pada seleksi pertumbuhan udang galah (Macrobrachium rosenbergii) dari generasi F-1-F-3 secara kumulatif adalah 33,68\%dengan kisaran setiap generasi $7,78 \% 10,44 \%$

Penelitian ini menunjukkan bahwa LPH rumput laut K. striatum lebih rendah dibandingkan dengan spesies rumput laut lainnya. Selama tiga siklus pemeliharaan, LPH yang didapatkan berkisar antara 2,26\%3,47\%hari; dibandingkan dengan LPH pada E. cottonii atau K. alvarezii sebesar 4,0\%11,0\% hari (Ohno et al., 1996); 4,5\%10,7\% hari (Paula et al., 2002); 1,6\%4,6\% hhari (Hung et al., 2009); 2,3\%6,1\% /hari (Thirumaran \& Anantharaman, 2009); and 1,6\%8,6\% /hari (Orbita, 2013). Nilai LPH yang kurang lebih sama dilaporkan oleh Adnan \& Porse (1987) sebesar 2,5\%3,5\%hari; dan

Tabel 1. Diferensial seleksi dan respons seleksi rumput laut Kappaphycus striatum berdasarkan laju pertumbuhan harian (LPH) setiap siklus pemeliharaan

Table 1. Selection differential and selection response of seaweed Kappaphycus striatum based on the daily growth rate (DGR) for each cultivation cycle

\begin{tabular}{|c|c|c|c|c|c|c|}
\hline \multirow{2}{*}{$\begin{array}{l}\text { Parameter } \\
\text { Parameters }\end{array}$} & \multirow{2}{*}{$\begin{array}{l}\text { Rerata LPH populasi } \\
\text { kontrol (\%hari) } \\
\text { Average of DGR } \\
\text { population control (\%day) }\end{array}$} & \multirow{2}{*}{$\begin{array}{c}\text { Rerata LPH populasi } \\
\text { seleksi (\%hari) } \\
\text { Average of DGR } \\
\text { population selection (\%day) }\end{array}$} & \multicolumn{2}{|c|}{$\begin{array}{l}\text { Diferensial seleksi* } \\
\text { Selection differential* }\end{array}$} & \multicolumn{2}{|c|}{$\begin{array}{l}\text { Respons seleksi** } \\
\text { Selection response** }\end{array}$} \\
\hline & & & $\%$ hari (\%day) & $\%$ & $\%$ hari (\%day) & $\%$ \\
\hline $\begin{array}{l}\text { Stok indukan } \\
\text { Parent stock }\end{array}$ & 3.02 & 3.02 & 2.27 & 75.17 & - & - \\
\hline $\begin{array}{l}\text { Siklus-1 } \\
\text { Cycle-1 }\end{array}$ & 1.13 & 2.26 & 1.52 & 67.26 & 1.13 & 100 \\
\hline $\begin{array}{l}\text { Siklus-2 } \\
\text { Cycle2 }\end{array}$ & 1.82 & 3.03 & 1.44 & 47.52 & 1.21 & 66.48 \\
\hline $\begin{array}{l}\text { Siklus-3 } \\
\text { Cycle-3 }\end{array}$ & 1.81 & 3.47 & - & - & 1.66 & 91.71 \\
\hline
\end{tabular}

Catatan (Notes):

* Setelah siklus-3, seleksi tidak dilakukan lagi untuk siklus berikutnya, tetapi hanya dilanjutkan dengan perbanyakan bibit (After cycle3, the selection was not performed for next cycle, but it was proceeded to the seed propagation)

** Estimasi respons seleksi dihitung hanya berdasarkan LPH seleksi dan kontrol internal karena proses produksi tidak melalui perkawinan (Estimation of response to selection based on DGR of selection and internal control, due to without the sexual mating process) 
Hurtado et al. (2001) sebesar 0,2\%4,2\% hari. Muslimin et al. (2014) melaporkan bahwa bahwa LPH rumput laut K. alvarezii adalah 0,9\%1,7\% hari yang dipelihara di perairan Parigi Moutong, Sulawesi Tengah. Penelitian terbaru oleh Sari et al. (2015) memperlihatkan bahwa LPH K. striatum adalah berkisar antara 1,01\%2,82\% /hari yang dipelihara dengan sistem IMTA (integrated multi tropic acuaculture) di Teluk Tomini, Gorontalo. LPH rumput laut K. striatum yang didapatkan dari penelitian ini dan beberapa penelitian sebelumnya menunjukkan nilai yang masih lebih kecil dari LPH yang disarankan oleh Anggadiredja et al. (2011) yakni tidak kurang dari 3\% hari. Meskipun demikian, LPH rumput laut K. alvarezii dapat mencapai $6,9 \% 8,8 \%$ hari dilaporkan oleh Pongmasak et al. (2015a) dengan penerapan teknik seleksi yang dilakukan di perairan Nusa Tenggara Barat.

Pertumbuhan rumput laut sangat dipengaruhi oleh kondisi lingkungan perairan tempat pembudidayaan dilakukan. Parenrengi et al. (2008) dan Pongmasak et al. (2009) merekomendasikan bahwa setiap sentra budidaya rumput laut sebaikya memiliki kalender musim yang dapat dijadikan acuan dalam menentukan kapan mulai penanaman dan spesies mana yang sesuai untuk dibudidayakan. Budidaya rumput laut K. alvarezii di Filipina juga memperlihatkan pertumbuhan yang dipengaruhi oleh musim dan kondisi lingkungan budidaya. Orbita (2013) melaporkan bahwa pertumbuhan rumput laut tertinggi terjadi pada musim "habagat" yang ditandai dengan gelombang yang relatif besar, suhu yang rendah, dan salinitas rendah dengan disertai hujan. Tetapi hasil penelitian yang berbeda dilaporkan oleh Hurtado et al. (2001) dan Hung et al. (2009) bahwa pada musim tersebut didapatkan pertumbuhan rumput laut yang rendah. Penelitian yang dilakukan oleh Pongmasak (2008) menunjukkan bahwa pertumbuhan rumput laut $K$. alvarezii dan E. denticulatum berkorelasi positif dengan lingkungan budidaya khususnya kandungan nitrat dan fosfat.

\section{Kandungan Karaginan dan Kekuatan Gel}

Kandungan karaginan rumput laut hasil seleksi relatif lebih tinggi dibandingkan dengan kontrol untuk semua siklus pemeliharaan. Pemeliharaan siklus-1, siklus-2, dan siklus-3, kandungan karaginan pada rumput laut hasil seleksi masing-masing mencapai 23,90\% $32,04 \%$ dan 30,36\%atau rata-rata $28,77 \%$ sedangkan kandungan karaginan rumput laut perlakuan kontrol adalah masing-masing $21,60 \% 30,25 \%$ dan $28,90 \%$ atau rata-rata $26,95 \%$ (Tabel 2). Hal tersebut dapat diasumsikan bahwa dengan penerapan seleksi maka peningkatan kandungan karaginan rumput laut K. striatum dapat mencapai 5,1\%10,6\% Peningkatan kandungan karaginan juga telah dilaporkan oleh Parenrengi et al. (2014) pada spesies rumput laut E. denticulatum sebesar $6,58 \%$ dan $\mathrm{K}$. alvarezii strain Takalar adalah 7,15\%

Hasil penelitian ini memberikan suatu gambaran bahwa ada kecenderungan pertumbuhan berkorelasi positif dengan kandungan karaginan rumput laut. Pertumbuhan K. striatum hasil seleksi yang lebih tinggi daripada kontrol juga didapatkan hal yang sama pada kandungan karaginan. Kandungan karaginan rumput laut hasil seleksi yang didapatkan pada penelitian ini berkisar antara 23,0\%32,04\% Kandungan karaginan rumput laut $K$. striatum relatif lebih rendah dibandingkan dengan rumput laut K. alvarezii yang berkisar $31,21 \% 42,98 \%$ tetapi masih lebih tinggi dibandingkan dengan $\mathrm{E}$. denticulatum yakni rata-rata 18,74\%(Parenrengi et al., 2014). Kandungan karaginan $\mathrm{K}$. alvarezii yang relatif sama dengan $\mathrm{K}$. striatum pada penelitian ini, telah dilaporkan oleh Muslimin et al. (2015) dengan kandungan karaginan sebesar 33,10\% $35,89 \%$ pada rumput laut yang dipelihara di perairan Teluk Tomini, Gorontalo. Kandungan karaginan pada rumput laut sangat dipengaruhi oleh umur pemeliharaan. Parenrengi (2013b) melaporkan bahwa semakin tua umur panen rumput laut semakin tinggi kandungan karaginannya sehingga disarankan umur

Tabel 2. Kandungan karaginan dan kekuatan gel pada Kappaphycus striatum hasil seleksi dan kontrol selama tiga siklus pemeliharaan

Table 2. Carrageenan content and gel strength of selected Kappaphycus striatum and control in three cycles of cultivation

\begin{tabular}{lccccc}
\hline $\begin{array}{c}\text { Parameter } \\
\text { Parameters }\end{array}$ & $\begin{array}{c}\text { Perlakuan } \\
\text { Treatments }\end{array}$ & $\begin{array}{c}\text { Siklus-1 } \\
\text { Cycle-1 }\end{array}$ & $\begin{array}{c}\text { Siklus-2 } \\
\text { Cycle2 }\end{array}$ & $\begin{array}{c}\text { Siklus-3 } \\
\text { Cycles-3 }\end{array}$ & $\begin{array}{c}\text { Rata-rata } \pm \text { SD } \\
\text { Average } \pm \text { SD }\end{array}$ \\
\hline Kandungan karaginan & Seleksi (Selection) & 23.90 & 32.04 & 30.36 & $28.77 \pm 4.30$ \\
Carrageenan content (\%) & Kontrol (Control) & 21.60 & 30.25 & 28.90 & $26.95 \pm 4.67$ \\
\hline Kekuatan gel & Seleksi (Selection) & 636.42 & 594.39 & 388.52 & $539.78 \pm 132.67$ \\
Gel strength $\left(\mathrm{g} / \mathrm{cm}^{2}\right.$ ) & Kontrol (Control) & 423.43 & 559.84 & 382.61 & $455.32 \pm 92.78$ \\
\hline
\end{tabular}


panen minimal 45 hari pemeliharaan. Pada penelitian ini, pengukuran kandungan karaginan dan kekuatan gel dilakukan pada umur 30 hari pemeliharaan pada saat bersamaan dengan sampling propagasi bibit hasil seleksi, sehingga kandungan karaginan rumput laut K. striatum dapat lebih tinggi jika pemeliharaan dilakukan sampai dengan 45 hari.

Seperti halnya dengan pertumbuhan rumput laut yang dipengaruhi oleh lingkungan, beberapa laporan menunjukkan bahwa kandungan karaginan juga dipengaruhi oleh faktor lingkungan seperti suhu, intensitas cahaya, dan nutrien atau kualitas perairan. Orbita (2013) melaporkan bahwa hasil penelitian yang dilkukan di Barangay Doña Consuelo, Ozamiz City menunjukkan bahwa pertumbuhan sangat dipengaruhi oleh konsentrasi nitrat di lingkungan perairan, sedangkan salinitas memberikan pengaruh yang besar terhadap kandungan karaginan K. alvarezii, seperti halnya di Brazil, pertumbuhan dan kandungan karaginan rumput laut dipengaruhi oleh suhu air dan salinitas tempat budidaya dilakukan.

Kekuatan gel rumput laut K. striatum yang didapatkan pada penelitian ini menunjukkan kecenderungan lebih tinggi pada perlakuan bibit hasil seleksi dibandingkan dengan kontrol. Perbedaan kekuatan gel tersebut terlihat pada siklus pertama yakni hasil seleksi sebesar $636,42 \mathrm{~g} / \mathrm{cm}^{2}$; sedangkan kontrol hanya $423,43 \mathrm{~g} / \mathrm{cm}^{2}$; dan pada siklus kedua dan ketiga perbedaan antara seleksi dengan kontrol relatif sedikit (Tabel 2). Jika pada siklus pertama, peningkatan kekuatan gel rumput laut dapat mencapai $50,3 \%$ sedangkan pada siklus kedua dan ketiga masingmasing adalah 6,2\%dan 1,5\% Parenrengi et al. (2014) melaporkan bahwa kekuatan gel rumput laut
K. alvarezii hasil seleksi lebih tinggi dibandingkan dengan kontrol, yakni 472,15 g/ $/ \mathrm{cm}^{2}$ dan $376,48 \mathrm{~g} / \mathrm{cm}^{2}$; tetapi hal yang berbeda didapatkan pada rumput laut spesies E. denticulatum di mana tidak ada perbedaan kekuatan gel antara seleksi $\left(164,52 \mathrm{~g} / \mathrm{cm}^{2}\right)$ dengan kontrol $\left(164,56 \mathrm{~g} / \mathrm{cm}^{2}\right)$.

Analisis korelasi sederhana yang dilakukan terhadap pertumbuhan rumput laut dengan kandungan karaginan dan kekuatan gel, menunjukkan bahwa hubungan antara pertumbuhan dengan kandungan karaginan $\left(R^{2}=0,4361\right.$ atau $\left.r=0,6604\right)$ memiliki korelasi yang lebih erat dibandingkan dengan kekuatan gel $\left(R^{2}=0,0110\right.$ atau $\left.r=0,1048\right)$. Hubungan kedua parameter tersebut disajikan pada Gambar 5. Tidak ada korelasi yang nyata antara kandungan agar dengan kekuatan gel rumput laut $K$. striatum $\left(R^{2}=0,0011\right.$ atau $r=0,0332$ ). Hal yang berbeda didapatkan pada rumput laut K. alvarezii di mana semakin tinggi kandungan karaginan maka semakin besar kekuatan gel yang dihasilkan $\left(R^{2}=0,821\right.$ atau $\left.r=0,906\right)$ (Parenrengi et al., 2014).

\section{Kualitas Air}

Data hasil pengamatan kondisi perairan yang meliputi salinitas, $\mathrm{pH}$, kandungan fosfat, dan nitrat selama penelitian berlangsung (pemeliharaan stok indukan sampai dengan siklus-3) disajikan pada Tabel 3. Salinitas dan pH tidak memperlihatkan fluktuasi yang nyata antar ketiga siklus pemeliharaan rumput laut K. striatum. Seperti halnya dengan $\mathrm{pH}$ dan salinitas, maka nitrat dan fosfat juga tidak memperlihatkan perbedaan yang tinggi antar ketiga siklus pemeliharaan. Meskipun demikian, nitrat, dan fosfat relatif lebih tinggi didapatkan pada siklus kedua dan

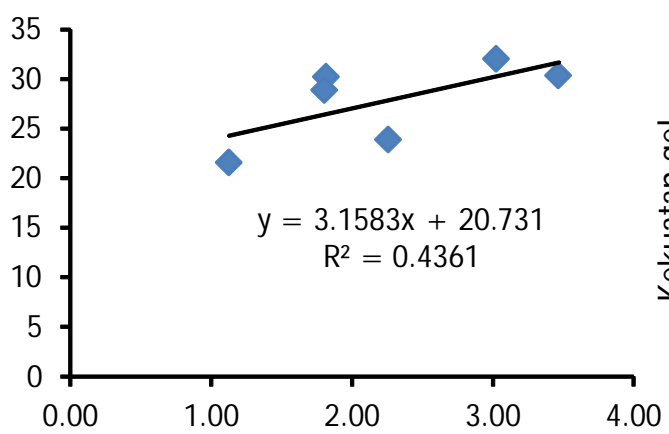

Laju pertumbuhan harian (\%hari) Daily growth rate (\%day)

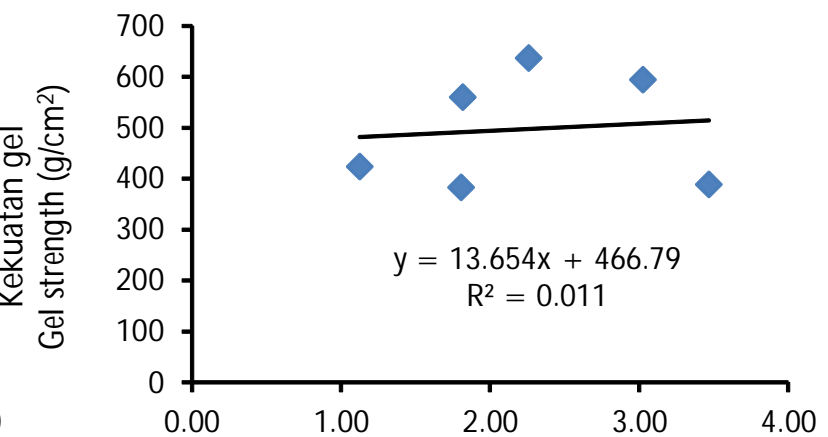

Laju pertumbuhan harian (\%hari) Daily growth rate (\%day)

B

Gambar 5. Korelasi antara laju pertumbuhan harian dengan kandungan karaginan (A) dan kekuatan gel rumput laut Kappahycus striatum

Figure 5. Correlation between carrageenan content (A) and gel strength (B) of seaweed Kappaphycus striatum 
Tabel 3. Parameter kualitas air yang diamati selama penelitian budidaya rumput laut

Table 3. Water quality parameters observed during the study of seaw eed cultivation

\begin{tabular}{lccc}
\hline $\begin{array}{c}\text { Parameter } \\
\text { Parameters }\end{array}$ & $\begin{array}{c}\text { Maksimal } \\
\text { Maximum }\end{array}$ & $\begin{array}{c}\text { Minimal } \\
\text { Minimum }\end{array}$ & $\begin{array}{c}\text { Rata-rata } \\
\text { Average }\end{array}$ \\
\hline Salinitas (Salinity) (ppt) & 34.60 & 34.43 & 34.48 \\
Nitrat (Nitrate) (mg/L) & 1.8822 & 0.1455 & 0.6594 \\
Fosfat (Phosphate) (mg/L) & 0.4072 & 0.0666 & 0.1734 \\
pH & 8.40 & 8.10 & 8.21 \\
\hline
\end{tabular}

ketiga. Hal tersebut diduga kuat berpengaruh pada pertumbuhan rumput laut $\mathrm{K}$. striatum lebih tinggi pada siklus kedua dan ketiga dibandingkan dengan siklus pertama.

Pada beberapa penelitian sebelumnya menunjukkan bahwa rumput laut $E$. isiforme telah ditemukan tumbuh optimal dengan respons fotosintesis yang tinggi pada salinitas 30-40 ppt sementara rumput laut E. uncinatum dan $\mathrm{E}$. denticulatum pada salinitas $30 \mathrm{ppt}$ (Ask \& Azanza, 2002). Dilaporkan juga bahwa kultur rumput laut K. striatum di laboratorium tidak mampu bertahan hidup pada salinitas di bawah 24 ppt atau di atas 45 ppt. Pirzan \& Pongmasak (2007) melaporkan bahwa kualitas air pada pemeliharaan rumput laut di Pulau Sugi, Pangkep, Sulawesi Selatan, seperti: pH, nitrat, amoniak, fosfat adalah masing-masing 8,4-8,5; 0,0013-0,0201 mg/L, 0,0133-0,1690 mg/L; 0,0001$0,0119 \mathrm{mg} / \mathrm{L}$. Penerapan seleksi varietas rumput laut K. alvarezii yang dilakukan di Boalemo, Gorontalo pada salinitas 25,37-31,89 ppt, tetapi Pongmasak \& Priono (2015) menyatakan bahwa dengan salinitas tersebut masih mampu mendukung produksi bibit unggul sampai dengan generasi-3 (G-3). Afrianto \& Liviawati (1993) menyatakan bahwa pertumbuhan optimal rumput laut pada salinitas antara 30-35 ppt. Orbita (2013) juga melaporkan bahwa suhu dan salinitas merupakan faktor lingkungan utama yang memengaruhi pertumbuhan K. alvarezii di Filipina di mana pertumbuhan maksimal didapatkan pada bulan Juni-September dengan suhu $27,67^{\circ} \mathrm{C}-30,72^{\circ} \mathrm{C}$ dan salinitas 23,60-29,80 ppt.

Nitrat dan fosfat memainkan peran penting dalam pertumbuhan alga termasuk rumput laut sedangkan nitrogen adalah faktor pembatas utama nutrien untuk pertumbuhan alga pada ekosistem laut. Keberhasilan budidaya rumput laut membutuhkan pengetahuan tentang kebutuhan nitrogen untuk alga. Martins et al. (2011) melaporkan bahwa kekurangan nutrien pada beberapa spesies alga dapat berdampak pada penurunan pertumbuhan akibat perubahan formasi dan penurunan kandungan protein dan phycobiliprotein terlarut. Pada peneltian ini, konsentrasi nitrat selama pemeliharaan berlangsung adalah 0,1455-1,8822 $\mathrm{mg} / \mathrm{L}$; masih cukup layak untuk pertumbuhan rumput laut, walaupun ada kecenderungan masih relatif rendah. Berdasarkan optimal konsentrasi yang disarankan oleh Atmadja et al. (1996) bahwa kisaran nitrat yang dapat mendukung pertumbuhan rumput laut adalah 0,9-3,5 $\mathrm{mg} / \mathrm{L}$. Hal ini berarti bahwa konsentrasi nitrat selama pemeliharaan didapatkan konsentrasi yang relatif rendah khususnya pada siklus-1. Kandungan nitrat yang terukur di daerah pemeliharaan rumput laut di Boalemo, Gorontalo 0,03-0,90 mg/L telah dilaporkan oleh Pongmasak \& Priono (2015).

Konsentrasi fosfat dalam penelitian ini adalah berkisar 0,0666-0,4072 mg/L selama periode pemeliharaan. Effendi (2000) menyatakan bahwa konsentrasi optimal fosfat dalam perairan untuk rumput laut adalah 0,1-3,5 mg/L; sehingga konsentrasi yang didapatkan relatif sesuai dengan kisaran tersebut dengan nilai rata-rata yang $0,1734 \mathrm{mg} / \mathrm{L}$. Fosfat adalah salah satu nutrien penting karena dapat berpartisipasi dalam formasi biomolekul seperti asam amino, protein, dan fosfolipit. Meskipun demikian, peran yang paling penting adalah transfer energi yang dimediasi oleh ATP dan komponen energi tinggi lainnya yang diperuntukkan untuk proses fotosintesis dan respirasi. Konsentrasi fosfat yang tinggi dapat menstimulasi pertumbuhan dan laju pertumbuhan alga dan juga dapat meningkatkan produksi karaginan (Martins et al., 2011).

Pongmasak (2008) melaporkan bahwa laju pertumbuhan rumput laut $K$. alvarezii dan E. denticulatum dipengaruhi oleh konsentrasi nitrat dan fosfat. Parameter kualitas air tersebut berkorelasi positif dengan laju pertumbuhan rumput laut. Ada kecenderungan semakin tinggi kandungan nitrat dan fosfat maka semakin besar kandungan karaginan yang dihasilkan. Hubungan yang erat $(r>0,5)$ antara kandungan nitrat dan fosfat dengan kandungan 
karaginan juga dilaporkan oleh Pongmasak \& Tjaronge (2009). Selanjutnya Mulyaningrum et al. (2009) melaporkan bahwa pembentukan kandungan karaginan pada rumput laut $K$. alvarezii berkorelasi erat denga suhu perairan $(r=0,99)$ dan transparansi $(r=0,79)$.

\section{KESIMPULAN DAN SARAN}

Seleksi varietas rumput laut dapat meningkatkan Iaju pertumbuhan rumput laut K. striatum. Laju pertumbuhan harian, kandungan agar, dan kekuatan gel rumput laut dari bibit hasil seleksi varietas memperlihatkan nilai yang lebih tinggi dibandingkan dengan bibit yang tidak diseleksi (kontrol). Laju pertumbuhan rumput laut memiliki korelasi yang erat dengan kandungan karaginan, tetapi relatif lebih rendah dengan kekuatan gel. Kualitas air perairan tempat pemeliharaan rumput laut masih dalam batas kesesuaian dalam mendukung pertumbuhan. Metode seleksi varietas menunjukkan potensi besar dalam penyediaan bibit unggul untuk pengembangan usaha budidaya.

\section{UCAPAN TERIMA KASIH}

Penelitian ini dibiayai dari kerja sama litbang BPPBAP, Maros dan ACIAR, Australia dengan nomor kesepahaman SMAR 2008 025: Improved seaweed culture and postharvest waste utilisation in South East Asia. Terima kasih khusus disampaikan kepada Dr. Alimuddin, dosen pada Institut Pertanian Bogor (IPB) atas bimbingan dan saran dalam penentuan diferensial seleksi dan estimasi respons seleksi rumput laut. Kami juga mengucapkan terima kasih kepada peneliti dan teknisi BPPBAP yang terlibat dalam penelitian ini.

\section{DAFTAR ACUAN}

Adnan, H., \& Porse, H. (1987). Culture of Eucheuma cottonii and Eucheuma spinosum in Indonesia. Hydrobiologia, 151-152, 355-358.

Afrianto, E., \& Liviawati, E. (1993). Budidaya laut dan cara pengolahannya. Bharata. Jakarta, $64 \mathrm{hlm}$.

Amini, S., \& Parenrengi, A. (1995). Pengaruh variasi komposisi pupuk terhadap pertumbuhan rumput laut Eucheuma cottonii pada kultur in vitro. J. Penelitian Perikanan Indonesia, 1(3), 47-54.

Anggadiredja, J.T., Zatnika, A., Purwoto, H., \& Istini, S. (2011). Rumput laut. Penebar Swadaya. Jakarta, hlm. 14-19.

Ask, E.A., \& Azanza, R.V. (2002). Advances in cultivation technology of commercial eucheumatoid species: a review with suggestions for future research. Aquaculture, 206, 257-277.
Atmadja, W.S., Kadi, A., Sulistidjo, \& Safari, R. (1996). Pengenalan jenis-jenis rumput laut di Indonesia. Puslitbang Oseanografi LIPI. Jakarta.

Effendi, H. (2000). Telaah kualitas air bagi pengelolaan sumberdaya dan lingkungan perairan. Jurusan Manajemen Sumberdaya Perairan, Fakultas Perikanan dan Ilmu Kelautan, IPB Bogor, 258 hlm.

Fadillah, S. (2014). Growth, morphology and growthrelated hormone level in Kappaphycus alvarezii produced by mass selection in Gorontalo Waters, Indonesia. HAYATI Journal of Biosciences, 1022, 112.

FAO. (2012). The state of world fisheries and aquaculture 2012. Rome, $230 \mathrm{pp}$.

FAO. (2015). Global aquaculture production statistics database updated to 2013. Summary information of Fisheries and Aquaculture Department. Rome, $4 \mathrm{pp}$.

Gunawan, L.W. (1987). Teknik kultur jaringan. Labo ratorium Kultur Jaringan Tanaman, Pusat Antar Universitas (PAU), Bioteknologi IPB, Bogor.

Hadie, L.E., \& Hadie, W. (2012). Evaluasi perkembangan budidaya rumput laut dalam mendukung industrialisasi perikanan. In Taufiqurrohman, M., Prayogi, U., \& Winarno, A. (Eds.). Prosiding Seminar Nasional Kelautan VIII. Universitas Hang Tuah. Surabaya, hlm. 32-38.

Hung, L., Hori, K., Nang, H., Kha, T., \& Hoa, L.T. (2009). Seasonal changes in growth rate, carrageenan yield and lectin content in the red alga Kappaphycus alvarezii cultivated in Camranh Bay, Vietnam. J. Appl. Phycol., 21, 265-272.

Hurtado, A., Agbayani, R., Sanares, R., \& CastroMallare, M. (2001). The seasonality and economic feasibility of cultivating Kappaphycus alvarezii in Panagatan Cays, Caluya, Antique, Philippines. Aquaculture, 199, 295-310.

Imron, Iswanto, B., Marnis, H., Suprapto, R., Suwargono, P., Ridzwan, N.S., Pangestika, M.F., Ilmalizanri, Didi, Suryana, A., Sofyan Suri, A.S., \& Tarmo. (2014). Naskah akademik ikan lele tumbuh cepat hasil seleksi individu. Balai Penelitian Pemuliaan Ikan (BPPI). Sukamandi, $166 \mathrm{hlm}$.

Marine Colloid (1977). Carrageenan marine colloid monograph number one. Marine Colloid Division FMC Coorporation, Springfield, New Jersey, USA.

Martins, A.P., Junior, O.N., Colepicolo, P., \& Yokoya, N.S. (2011). Effects of nitrate and phosphate availabilities on growth, photosynthesis and pigment and protein contents in colour strains of Hypnea musciformis (Wulfen in Jacqu.) J.V. Lamour. (Gigartinales, Rhodophyta). Rev. Bras. Farmacogn., 21(2), 1-18. 
Ma'ruf, W.F. (2013). Institution support to the Indonesian seaweed industries. Paper presented at Indonesia-FAO Regional Workshop on Seaweed Culture, Handling, and Processing. Jakarta, October 3-6, 2013.

Mulyaningrum, S.R.H., Pongmasak, P.R., \& Suryati, E. (2009). Kandungan karagenan enam strain rumput laut Kappaphycus alvarezii di perairan Polewali Mandar, Sulawesi Barat. Dalam Sudradjat, A., Supriyadi, H., Hanafi, A., Kristanto, A.H., Chumaidi, Mustafa, A., Imron, \& Insan, I. (Eds.). Prosiding Forum Inovasi Teknologi Akuakultur 2009. Pusat Riset Perikanan Budidaya. Jakarta, hlm. 766771.

Mulyaningrum, S.R.H., Parenrengi, A., Risjani, Y., \& Nursyam, H. (2013). Formulasi auksin (indole acetic acid) dan sitokinin Ikinetin, zeatin) untuk morfogenesis serta pengaruhnya terhadap pertumbuhan, sintasan, dan laju regenerasi kalus rumput laut, Kappaphycus alvarezii. J. Ris. Akuakultur, 8(1):31-41.

Muslimin, Pongmasak, P.R., \& Adhiyudarto, B. (2014). Pengamatan pertumbuhan rumput laut Kappaphycus alvarezii dengan metode long line di perairan Parigi Moutong Provinsi Sulawesi Tengah. Dalam Sugama, K., Kusnendar, E., Rachmansyah, Giri, N.A., Yuhana, M., Kristanto, A.H., Imron, Radiarta, I N., \& Dewi, R.R.S.P.S. (Eds.). Prosidng Forum Inovasi Teknologi Akuakultur 2014. Pusat Penelitian dan Pengembangan Perikanan Budidaya. Jakarta, hlm. 145-153.

Muslimin, Sari, W.K.P., \& Adhiyudanto, N.B. (2015). Performansi pertumbuhan dan kandungan karaginan rumput laut Kappaphycus alvarezii yang dibudidayakan pada lokasi yang berbeda di perairan Teluk Tomini, Gorontalo. Dalam Sugama, K., Kristanto, A.H., Radiarta, I N., Lusiastuti, A.M., Kusdiarti, Priona, B., Insan, I., Dewi, R.R.S.P., \& Gardenia, L. (Eds.). Prosiding Forum Inovasi Teknologi Akuakultur 2015. Pusat Penelitian dan Pengembangan Perikanan Budidaya. Jakarta, hlm. 973-978.

Ohno, M., Nang, H., \& Hirase, S. (1996). Cultivation and carrageenan yield and quality of Kappaphycus alvarezii in the waters of Vietnam. J. Appl. Phycol., 8, 431-437.

Orbita, M.L.S. (2013). Growth rate and carrageenan yield of Kappaphycus alvarezii (Rhodophyta, Gigartinales) cultivated in Kolambugan, Lanao del Norte, Mindanao, Philippines. AAB Bioflux, 5(3), 128-139.

Paena, M., Hasnawi, \& Mustafa, A.A. (2010). Analisis data dukung strategi pengembangan budidaya rumput laut di perairan pesisir Kabupaten Mamuju,
Provinsi Sulawesi Barat. Dalam Sudradjat, A., Rachmansyah, Hanafi, A., Azwar, Z.I., Imron, Kristanto, A.H., Chumaidi, \& Insan, I. (Eds.). Prosiding Forum Inovasi Teknologi Akuakultur 2010. Pusat Penelitian dan Pengembangan Perikanan Budidaya. Jakarta, hlm. 1129-1137.

Parenrengi, A., Sulaeman, Suryati, E., \& Tenriulo, A. (2006). Karakterisasi genetik rumput laut Kappaphycus alvarezii yang dibudidayakan di Sulawesi Selatan. J. Ris. Akuakultur, 1(1), 01-11.

Parenrengi, A., Sulaeman, Suryati, E., \& Tenriulo, A. (2007). Karakteristik genetik rumput laut Gracilaria verrucosa dari beberapa sumber. Jurnal Aquacultura Indonesiana, 8(3), 177-182.

Parenrengi, A., Rachmansyah, \& Suryati, E. (2008). Budidaya rumput laut bekelanjutan dengan dukungan teknologi penyediaan benih secara in vitro. Dalam Supriyadi, H., Hanafi, A., Kristanto, A.H., Chumaidi, Mustafa, A., Imron, \& Insan, I. (Eds.). Teknologi Perikanan Budidaya 2008. Pusat Riset Perikanan Budidaya. Jakarta, hlm. 25-38.

Parenrengi, A. (2013a). Seaweed culture in Indonesia. Paper presented at Indonesia-FAO Regional Workshop on Seaweed Culture, Handling, and Processing. Jakarta, October 3-6, 2013.

Parenrengi, A. (2013b). Budidaya rumput laut kotoni Kappaphycus alvarezii: prospek dan permasalahannya. Makalah disampaikan pada "Pelatihan Budidaya Rumput Laut" pada tanggal 2223 Desember 2013 di Nunukan, Kalimantan Utara, $16 \mathrm{hlm}$.

Parenrengi, A., Dworjanyn, S., Rachmansyah, Pongmasak, P.R., \& Fahrur, M. (2014). Strain selection for growth enhancement of wild and cultivated eucheumatoid seaweed species in Indonesia. Laporan Hasil Penelitian Kerja sama Balai Penelitian dan Pengembangan Budidaya Aair Payau dengan ACIAR Australia, $18 \mathrm{hlm}$.

Paula, E.J., Pereira, R.T.L., \& Ohno, M. (2002). Growth rate of the carrageenophyte Kappaphycus alvarezii (Rhodophyta, Gigartinales) introduced in subtropical waters of São Paulo State, Brazil. Phycological Research, 50(1), 1-9.

Pirzan, A.M., \& Pongmasak, P.R. (2007). Studi budidaya rumput laut di Pulau Saugi, Kabupaten Pangkep, Sulawesi Selatan. Dalam Taufiqurrohman, M., Prayogi, U., Giman, \& Winanro, A. (Eds.). Prosiding Seminar Saional Kelautam III. Universitas Hang Tuah. Surabaya, hlm. 4348.

Pongmasak, P.R. (2008). Hubungan ketersediaan nitrogen dan fosfat dalam perairan terhadap pertumbuhan rumput laut di Kabupaten Bantaeng, Sulawesi Selatan. Dalam Permadi, A., Sipahutar, Y.H., Saifurridjal, Basith, A., Sugriwa, E., Siregar, 
A.N., Thaib, E.A., Puwanto, \& Sanofa, V. (Eds.). Prosiding Seminar Nasional Perikanan Indonesia 2008, hlm. 640-647.

Pongmasak, P.R., \& Tjaronge, M. (2009). Hubungan kandungan nitrogen dan fosfor pada perairan berbeda dengan kandungan karaginan rumput laut, Kappaphycus alvarezii. Dalam Sudradjat, A., Supriyadi, H., Hanafi, A., Kristanto, A.H., Chumaidi, Mustafa, A., Imron, \& Insan, I. (Eds.). Prosiding Forum Inovasi Teknologi Akuakultur 2009. Pusat Riset Perikanan Budidaya,hlm. 1165-1171.

Pongmasak, P.R., Tjaronge, M., \& Madeali, M.M. (2009). Musim tanam rumput laut di perairan Tonra, Kabupaten Bone, pantai Timur Sulawesi Selatan. Dalam Sudradjat, A., Supriyadi, H., Hanafi, A., Kristanto, A.H., Chumaidi, Mustafa, A., Imron, \& Insan, I. (Eds.). Prosidng Forum Inovasi Teknologi Akuakultur 2009. Pusat Riset Perikanan Budidaya. Jakarta, hlm. 413-421.

Pongmasak, P.R. (2010). Pencegahan hama dan penyakit rumput laut Kappaphycus alvarezii. Dalam Syamsuddin, S., Si pahutar, Y.H., Safurridjal, Basith, A., Nurbani, S.Z., Suharto, Siregar, A.N., Rahardjo, S., Surya, R., \& Sanofa, V. (Eds.). Prosiding Seminar Nasional Perikanan Indonesia 2010, Jakarta, hIm. 447454.

Pongmasak, P.R., \& Tjaronge, M. (2010). Performansi pertumbuhan dan kandungan karaginan rumput laut, Kappaphycus alvarezii dengan aplikasi budidaya vertikultur. Dalam Syamsuddin, S., Sipahutar, Y.H., Safurridjal, Basith, A., Nurbani, S.Z., Suharto, Siregar, A.N., Rahardjo, S., Surya, R., \& Sanofa, V. (Eds.). Prosiding Seminar Nasional Perikanan Indonesia 2010, Jakarta, hIm. 434-438.

Pongmasak, P.R., Asaad, A.I.J., Hasnawi, Pirzan, A.M., \& Lanuru, M. (2010). Analisis kesesuaian lahan untuk pengembangan budidaya rumput laut di Gusung Batua, Pulau Badi, Kabupaten Pangkep, Sulawesi Selatan. J. Ris. Akuakultur, 5(2), 299-316.

Pongmasak, P.R., Parenrengi, A., Rachmansyah, \& Suryati, E. (2011). Protokol seleksi varietas bibit unggul rumput laut. Balai Riset Perikanan Budidaya Air Payau, Pusat Penelitian dan Pengembangan Perikanan Budidaya, Badan Penelitian dan Pengembangan Kelautan dan Perikanan. Jakarta, $27 \mathrm{hlm}$.

Pongmasak, P.R., Sahrijannah, A., \& Septiningsih, E. (2013). Penentuan "cut off " seleksi varietas untuk produksi unggul rumput laut Gracilaria verrucosa cepat tumbuh. Dalam Insnansetyo, A. (Ed.). Prosiding Seminar Nasional Tahunan X Hasil Penelitian Kelautan dan Perikanan. Universitas Gajah Mada. Jogjakarta, hlm. 1-9.
Pongmasak, P.R., Kristanto, A.H., Kusdiarti, \& Kusnendar, E. (2014). Peningkatan produktivitas dan keuntungan budidaya rumput laut Kappaphycus alvarezii menggunakan bibit unggul hasil seleksi varietas. Dalam Sugama, K., Kusnendar, E., Rachmansyah, Giri, N.A., Yuhana, M., Kristanto, A.H., Imron, Radiarta, I N., \& Dewi, R.R.S.P.S. (Eds.). Prosidng Forum Inovasi Teknologi Akuakultur 2014. Pusat Penelitian dan Pengembangan Perikanan Budidaya. Jakarta, hlm. 123-135.

Pongmasak, P.R., Kristanto, A.H., Insan, I., \& Kusnendar, E. (2015). Penerapan seleksi varietas untuk produksi bibit unggul pada kawasan budidaya rumput laut Kappaphycus alvarezii di Teluk Serewe, Lombok Timur, Nusa Tenggara Barat. Dalam Sugama, K., Kristanto, A.H., Radiarta, I N., Lusiastuti, A.M., Kusdiarti, Priono, B., Insan, I., Dewi, R.R.S.P.S., \& Gardenia, L. (Eds.). Prosiding Forum Inovasi Teknologi Akuakultur 2015. Pusat Penelitian dan Pengembangan Perikanan Budidaya. Jakarta, hlm. 713-725.

Pongmasak, P.R., \& Priono, B. (2015). Pengembangan bibit rumput laut, Kappaphycus alvarezii dengan metode seleksi varietas di Boalemo, Gorontalo. Dalam Sugama, K., Kristanto, A.H., Radiarta, I N., Lusiastuti, A.M., Kusdiarti, Priono, B., Insan, I., Dewi, R.R.S.P.S., \& Gardenia, L. (Eds.). Prosiding Forum Inovasi Teknologi Akuakultur 2015. Pusat Penelitian dan Pengembangan Perikanan Budidaya. Jakarta, hlm. 727-743.

Priono, B., \& Andriyanto, S. (2012). Strategi dan kebijakan pengembangan rumput laut di Kabupaten Brebes, Jawa Tengah. Dalam Haryanti, Rachmansyah, Sugama, K., Parenrengi, A., Sudradjat, A., Imron, Sunarto, A., Sumiarsa, G.S., Azwar, Z.I., \& Kristanto, A.H. (Eds.). Prosiding Indoaqua-Forum Inovasi Teknologi Akuakultur 2012. Pusat Penelitian dan Pengembanan Perikanan Budidaya. Jakarta, hlm. 1406-1412.

Radiarta, I N., Saputra, A., \& Albasri, H. (2012). Pemetaan kelayakan lahan budidaya rumput laut (Kappaphycus alvarezii) di Kabupaten Bintan Provinsi Kepulauan Riau dengan pendekatan sistem informasi geografis dan penginderaan jauh. J. Ris. Akuakultur, 7(1), 145-157.

Raikar, S.V., Lima, M., \& Fujita, Y. (2001). Effect of temperature, salinity, and light intensity on the growth of Gracilaria spp. (Gracilaridae, Rhodophyta) from Japan, Malaysia, and India. Indian Journal of Marine Sciences, 30(2), 98-104.

Rohmana, D., Sutomo, H., Rosellia, S., Tisnawibowo, K., Santika, A., Hastuti, S., Bunga, Nendih, Murtiarti, Wahyuni, T., \& Kurnia, A. (2014). Ade Kurnia: naskah akademik udang galah hasil seleksi 
individu pada karakter pertumbuhan. Balai Besar Perikanan Budidaya Air Tawar. Sukabumi, $55 \mathrm{hlm}$.

Sari, W.K.P., Muslimin, \& Simatupang, N.F. (2015).

Pertumbuhan rumput laut Kappaphycus alvarezii, Eucheuma denticulatum, dan Eucheuma striatum pada budidaya laut berbasis Integrated Multi Trophic Aquaculture (IMTA) di Teluk Tomini, Gorontalo. Dalam Sugama, K., Kristanto, A.H., Radiarta, I N., Lusiastuti, A.M., Kusdiarti, Priono, B., Insan, I., Dewi, R.R.S.P.S., \& Gardenia, L. (Eds.). Prosiding Forum Inovasi Teknologi Akuakultur 2015. Pusat Penelitian dan Pengembangan Perikanan Budidaya. Jakarta, hlm. 839-846.

Suhaimi, R.A., Makmur, \& Mustafa, A.S. (2012). Evaluasi kesesuaian Iahan untuk budidaya rumput laut (Kappaphycus alvarezii) di kawasan pesisir Kabupaten Pohuwato Provinsi Gorontalo. Dalam Haryanti, Rachmansyah, Sugama, K., Parenrengi, A., Sudradjat, A., Imron, Sunarto, A., Sumiarsa,
G.S., Azwar, Z.I., \& Kristanto, A.H. (Eds.). Prosiding Indoaqua-Forum Inovasi Teknologi Akuakultur 2012. Pusat Penelitian dan Pengembangan Perikanan Budidaya. Jakarta, hlm. 828-840.

Sulaeman, Parenrengi, A., Suryati, E., \& Tenriulo, A. (2007). Genetic, coloration and growth performance of two different varieties of Kappaphycus alvarezii. Indonesian Aquaculture Journal, 2(1), 2326.

Suryati, E., Mulyaningrum, S.R.H., Tenriulo, A., \& Rosmiati. (2008). Isolasi dan fusi protoplas rumput laut Kappaphycus alvarezii. Teknologi Perikanan Budidaya. Pusat Riset Perikanan Budidaya. Jakarta, hlm. 269-274.

Thirumaran, G., \& Anantharaman, P. (2009). Daily growth rate of field farming seaweed Kappaphycus alvarezii (Doty) Doty ex P. Silva in Vellar Estuary. World Journal of Fish and Marine Sciences, 1(3), 144-153. 